\title{
Does meaning matter? Nietzsche, Jung and implications for global leadership
}

\begin{tabular}{|c|c|}
\hline \multicolumn{2}{|c|}{$\begin{array}{l}\text { Authors: } \\
\text { Martina L. Mabille }{ }^{1} \text { (D) } \\
\text { Yolande Steenkamp }\end{array}$} \\
\hline \multicolumn{2}{|c|}{$\begin{array}{l}\text { Affiliations: } \\
{ }^{1} \text { The Unit For Reformational } \\
\text { Theology and the } \\
\text { Development of South } \\
\text { African Society, Faculty of } \\
\text { Theology, North-West } \\
\text { University, Potchefstroom, } \\
\text { South Africa }\end{array}$} \\
\hline \multicolumn{2}{|c|}{$\begin{array}{l}{ }^{2} \text { Department of Business } \\
\text { Management, Faculty of } \\
\text { Economic and Management } \\
\text { Sciences, University of } \\
\text { Pretoria, Pretoria, } \\
\text { South Africa }\end{array}$} \\
\hline \multicolumn{2}{|c|}{$\begin{array}{l}\text { Corresponding author: } \\
\text { Yolande Steenkamp, } \\
\text { ysteenka@gmail.com }\end{array}$} \\
\hline \multicolumn{2}{|c|}{$\begin{array}{l}\text { Dates: } \\
\text { Received: } 01 \text { Aug. } 2020 \\
\text { Accepted: } 05 \text { Feb. } 2021 \\
\text { Published: } 22 \text { Apr. } 2021\end{array}$} \\
\hline \multicolumn{2}{|c|}{$\begin{array}{l}\text { How to cite this article: } \\
\text { Mabille, M.L. \& Steenkamp, Y., } \\
\text { 2021, 'Does meaning matter? } \\
\text { Nietzsche, Jung and } \\
\text { implications for global } \\
\text { leadership', HTS Teologiese } \\
\text { Studies/Theological Studies } \\
\text { 77(3), a6284. https://doi. } \\
\text { org/10.4102/hts.v77i3.6284 }\end{array}$} \\
\hline \multicolumn{2}{|c|}{$\begin{array}{l}\text { Copyright: } \\
\text { (C) 2021. The Authors. } \\
\text { Licensee: AOSIS. This work } \\
\text { is licensed under the } \\
\text { Creative Commons } \\
\text { Attribution License. }\end{array}$} \\
\hline \multicolumn{2}{|l|}{ Read online: } \\
\hline 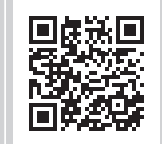 & $\begin{array}{l}\text { Scan this QR } \\
\text { code with your } \\
\text { smart phone or } \\
\text { mobile device } \\
\text { to read online. }\end{array}$ \\
\hline
\end{tabular}

The Global Risks 2035 Update by the Atlantic Council, despite its clinical focus on economic, environmental and security challenges, nevertheless suggests that shared global meaning might have a role to play in enabling humanity to set off on a more beneficial trend for its foreseeable global future. The realisation that the complex challenges facing humanity is existential as much as it is pragmatic necessitates trans-disciplinary engagement and collaborative research ventures. This article contributed a trans-disciplinary reflection by bringing philosopher Friedrich Nietzsche and psychologist-philosopher Carl Jung in dialogue with critical leadership studies within the broader framework of the science-religion dialogue of this special volume. Pointing to the awareness in leadership studies of how meaning, narrative and shared vision enable greater effectiveness and collaboration, we explore nihilism as cultural problem to be addressed in order to create meaning that fosters global collaborative action. From the viewpoint of the Global Risk 2035 Update and its gloomy strategic foresight of a newly bipolarised world or further descent into chaos, the article brought Nietzsche's idea of the Last Man into dialogue with Carl Jung's emphasis on the need for a collective myth to reverse the decline of civilisation and enable humanity to chart a course towards unprecedented global collaboration.

Contribution: The article contributes from a transdisciplinary perspective to the question of meaning in leadership. Drawing from the contributions of Nietzsche and Jung, it argues that shared myth and shared meaning is vital to address the complex global challenges that leadership is called to address. This philosophical reflection on the crisis of nihilism contributes to the growing awareness in critical leadership studies that meaning-making is critical to effective leadership.

Keywords: leadership; meaning; myth; meta-narrative; Nietzsche; Jung; Death of God; nihilism; Vocatus atque non vocatus; deus aderit.

\section{Introduction ${ }^{1}$}

In the classic Mentor series in the history of philosophy published between 1954 and 1963, the editors (which include luminaries such as Stuart Hampshire and Sir Isiah Berlin) chose to capture each era under a single descriptive epithet. Thus, we get titles ranging from The Age of Belief: The Medieval Philosophers (Fremantle 1955) to The Age of Reason: The Seventeenth Century Philosophers (Hampshire 1956) and The Age of Enlightenment: The Eighteenth Century Philosophers (Berlin 1956). The 20th century is quaintly labelled 'The Age of Analysis' (White 1956), referencing the rise of positivism and analytical thought. There the series ends. It is tempting to describe the 21st century as the Age of Anxiety: Despite the continuing optimism of public intellectuals ranging from free-market prophets to defenders of the 'Enlightenment project' such as Steven Pinker and Daniel Dennett who assure us that we are better off than ever before in history - there is a distinct pessimism sweeping through the coronavirus disease (COVID)threatened world. This pessimism can be detected from formal philosophy to traditional media and of course, social media.

The reason for this can perhaps be described in the well-known Lyotardian term 'the end of faith in metanarratives' - the demise of the belief in a standing reserve of good alternatives to our present situation (Lyotard 1984). Lyotard drew upon a more radical antecedent, Friedrich Nietzsche, who originally diagnosed the ills of the late modern West in terms of falling into a condition of nihilism - the radical devaluation of values. An interesting echo of the idea of 1.The Delphic Oracle in Latin, which Carl Jung had carved above the door to his house: 'Invoked or not invoked, the god will be present'.

Note: Special Collection: South African Science and Religion Forum, sub-edited by Wessel Bentley (UNISA). 
nihilism as a threat to contemporary society comes from the Atlantic Council's update to the Global Risks 2035 Report. When they published this update in October 2019, they postulated three scenarios for the global geopolitical future that ranged from promising to undesirable to catastrophic (Burrows 2019:10-12). To a large extent, the latter two scenarios rested on international relations between the United States of America and China and whether a new global bipolarity would emerge, on the one hand, or widespread economic meltdown, on the other. Merely a few months later, with the world gripped by a global pandemic, the scenarios on the more pessimistic side of the scale, or even a combination of them, seem all the more likely. Yet our concern in this article is less with global politics and international trade relations - or the outcome of the generational struggle between authoritarian state capitalism and democratic market capitalism (Kempe 2020:n.p.) - and more with the question regarding the role and function of meaning in a global society, and therefore in global leadership. Likewise, our interest in the Global Risks 2035 Report Update is less in the scenarios that it sketches and more in how it hints at shared meaning (and the lack thereof) as significant determinants of the shape our future may take. In its conclusion to the Report Update, the author makes an implicit reference to meaning when he describes 'a world in need of transformation' that requires 'a political, intellectual and, some say, spiritual renaissance' if it is to build a collective future (Burrows 2019:76). Towards the end of the conclusion, this is stated more explicitly (Burrows 2019):

The main characteristics of our postmodern age is the lack of a new global meta-narrative that advances beyond the benefits and disadvantages of globalization, binding developed and developing countries in a common mission towards solving the existential challenges of climate change, more deadlier conflict and the absence of social cohesion. (p. 77)

This places an odd requirement on global leadership, which is usually defined in narrow politico-economical terms. The complex and adaptive, or 'wicked' problems that might pull the world ever further toward a trajectory of chaos, demand, it would seem, a thorough engagement with the problem of nihilism. With this article, we wish to make a start, although we are aware that the question of meaning needs to be addressed specifically to particular regions and nations as well. Here, our focus is on the need to create meaning that will enable global collaboration to address wicked problems. The Update to the Global Risks report (2019) ended its projections by referring to Nietzsche and Jung's separate descriptions of the problem on nihilism. This article continues this discussion by suggesting that Nietzsche and Jung also offer unique insights in addressing these problems. We proceed by providing a brief overview of the question of meaning from the perspective of critical leadership studies before taking a deep dive into Nietzsche's thoughts on nihilism. We offer a brief description of Jung's take on this collapse in meaning and the need for a new myth of meaning to reverse this decline of civilisation. We conclude by returning to leadership and the concrete global problems, which a newly mythologised world is to address.

\section{Meaning-making in leadership: A brief overview}

The idea that meaning is a significant component of effective leadership is not new. Whilst earlier approaches to leadership tended to be leader-centric and focused more on vertical relations, recently the emphasis is shifting more towards appreciating leadership as an influencing process between leaders and followers (cf. Day \& Antonakis 2012:5). These emerging approaches to leadership have described the importance of meaning from a number of perspectives. Whilst not comprehensive, the following is offered as orientation for the reader: The importance of shared vision and purpose as determinants for shared leadership has been well demonstrated (Carson, Tesluk \& Marrone 2007). Relational leadership, which emphasises dynamic processes rather than individual 'big man' leaders, has been developed as 'meaningful co-action' (Conway 2015). Here the emphasis is that ongoing social processes and shared practices give rise to and construct social meaning, which in turn becomes a mechanism through which social relations amongst participants are sustained (Conway 2015:194). Uhl-Bien (2006:355) had contributed significantly in creating awareness of relational orientations to leadership that entails interdependent relationships and intersubjective meaning. Referring to Bradbury and Lichtenstein's (2000) notion of multiple meanings that continuously emerge and to Dachler and Hosking's (1995) reminder that socio-cultural contexts limit meaning, she points out that (Uhl-Bien 2006):

\footnotetext{
... knowing is always a process of relating; relating is a constructive, ongoing process of meaning making - an actively relational process of creating (common) understandings on the basis of language; meaning can never be finalized, nor has it any ultimate origin, it is always in the process of making; and meanings are limited by socio-cultural contexts'. (p. 355)
}

This illustrates well the prominence of constructionist approaches to leadership in contemporary leadership theory. A number of contributions in the responsible leadership approach have similarly pointed to this aspect of shared meaning-making and common purpose (Maak \& Pless 2019). In their outline of the roles of responsible leaders, Maak and Pless have significantly described such a leader, from a relational point of view, as a 'storyteller and meaning enabler', stating that 'as creator and communicator of moral experience and shared systems of meaning a leader has the task to breathe life into both individual and organisational responsibility' (2006:111). Whilst brief, this overview has sufficiently oriented the reader in terms of current approaches to the relevance of meaning in leadership studies. In what follows, it will become clear that the mythological dimensions explored by Nietzsche and Jung in relation to nihilism in contemporary society go much deeper. We will return to this notion in the conclusion. 


\section{Nihilism: Nietzsche and Jung in dialogue}

In this section, we return to the idea of the anxiety that grips today's world because of the nihilism described by Lyotard's reference to humanity having withdrawn her faith in metanarratives on an unprecedented scale. We consider the contribution of Friedrich Nietzsche before bringing him into dialogue with Carl Jung.

\section{Nietzsche, nihilism and the death of God}

To a significant extent, Nietzsche's project may be described as finding a cure for the 'wound' which Schiller claimed modernity inflicted upon modern humanity. Nietzsche himself adopts an aesculapian vocabulary to address the question of modernity: on more than one occasion he refers to himself as a 'physiological' or 'psychological' physician diagnosing modern culture as having lost its vigour and potential (i.e. Nietzsche 1968:26, 28). Nietzsche's word for Schiller's wound is nihilism. It may be superficially encountered in terms of a milquetoast world of the 'dampening of the feeling of life, mechanical activity, modest pleasures ...' (Nietzsche 2007:100), ${ }^{2}$ which threatens to slide into a state of decadence, unbridled excess and ultimately a state of perpetual anxiety. On a more serious level, it designates a generalised loss of meaning, authority and values, such 'that the highest values devalue themselves' (Nietzsche 1968:7). Nietzsche saw the modern humanity of his day as increasingly living in a state of quiet but absolute unbelief, in which no values are legitimate and moral laws are followed more out of habit than conviction.

For Nietzsche, the question of nihilism is generated by the internal logic of the West's most cherished beliefs, in particular its determined belief in metaphysical certitude. Latter-day nihilism may be traced to the original ascetic origins of the Western metaphysical tradition. The ascetic impulse is perhaps best understood in terms of the problem to which Nietzsche claims asceticism provides an answer: the problem of suffering. As creatures are subject to contingency, whether through their relationship with nature or with each other, human beings are subject to suffering. With the development of consciousness (Selbstbewussein), the problem was compounded: not only was suffering as terrible as it had always been, but as human beings became increasingly aware of their own mortality, the need arose to find a satisfactory answer as to why humanity was subject to suffering (Nietzsche 2007):

This is what the ascetic ideal meant: something was missing, there was an immense lacuna around man [sic], - he himself could think of no justification or explanation or affirmation, he suffered from the problem of what he meant. Other things made him suffer too, in the main he was a sickly animal: but suffering itself was not his problem, instead, the fact that there was no answer to the question he screamed, 'Suffering for what?' Man,

2.According to Slavoj Zizek, moderation has become a veritable injunction. Hence our obsession with a litany of products 'deprived of their malignant properties: coffee without caffeine, cream without fat, beer without alcohol ...' (Zizek 2002:10). [sic] the bravest animal and most prone to suffer, does not deny suffering as such: he wills it, he even seeks it out, provided he is shown a meaning for it, a purpose of suffering. The meaninglessness of suffering, not the suffering, was the curse that has so far blanketed mankind [sic], - and the ascetic ideal offered man a meaning! (p. 120)

Nietzsche is perfectly upfront about the sheer genius of the ascetic ideal. Plato, and the Christian tradition that followed in his wake, succeeded in giving suffering an interpretation. It explained suffering at the hand of a redemptive logic: the bite of travail was rendered as less than real, or at the very most temporary, to be compensated for in the realm of the actual. From Plato's domain of the Forms to the Christian heaven and Hegel's notion of the Real to be revealed at the end of the dialogic overcoming of alienation, for Nietzsche Western metaphysics bears witness to a long history of escape mechanisms. For Nietzsche, the question on the existence of the divine is less important than what the divine signifies. How the divine is formulated can serve as an index as to the health of a people, as it projects the needs of a particular group. With their amoral polytheism, the Greeks reflect health and the affirmation of life. Monotheism on the other hand, reflects a detachment from lived life and cultural practices, the conception of truth in purely abstract terms, the mummification of ideals and the crushing of humanity. It presents an impossible ideal, and concomitantly, the premature stagnation of a people. Nietzsche traces the metaphysical grounding for all the monotheism in Platonism. It implies the positing of another world over and against the world of becoming, true being conceived in terms of substance and thinking in terms of subject and predicate hence his famous proclamation that we will not get rid of God until we address the question of grammar (Nietzsche 2002:54). When God as 'measuring mechanism' became too Platonic and thus at a distance from worldly existence, Protagoras's dictum became particularly relevant - man [sic] has no choice but to become the measurer of all things. However, it is at this point that nihilism becomes a serious problem, because the subject is as much a product of his or her world as its measure.

Whether expressed in mathematical, spiritual or historical terms, metaphysics resulted from the abstraction and idealisation of the ideal aspects of reality. A distinction is usually made between the 'real' and 'apparent' worlds during which the 'real' is accorded the unitary status of 'truth'. Concomitantly, this 'truth' is endowed with inestimable value, and a realist account of truth develops with truth seen as final and complete (only to be discovered). As Foucault reminds us, the discovery of this truth then becomes an absolute imperative, and the truth is usually only allowed to be expressed in acceptable forms of discourse. This 'will to truth' amounts to a hatred of (Nietzsche 2007):

... the human, and even more of the animalistic, even more of
the material, this horror of the senses, of reason itself, this fear
of happiness and beauty, this longing to get away from
appearance, transience, growth, death, wishing, longing itself Open Access 
[...] an aversion to life, a rebellion against the most fundamental prerequisites of life. (p. 120)

For Nietzsche, this came at a terrible price: the tragic nature of reality was denied and the denial of chance, contingency and fate led to a denial of some of the most fertile aspects of existence and ultimately, the denial of the fundamental nature of the world. Above all, it led to the crafting of a form of selfhood, which took itself out of the world and set it up against it in the clinical relationship of subject and object the transcendental form of subjectivity, which has been haunting the West since Descartes. It is a strategy that worked well for a remarkably long time, well over 2000 years, as Nietzsche associates the birth of asceticism with Platonism. Unfortunately, it could not last forever. Christianity carried within it the seeds of its own destruction: it mistook transcendental (i.e. necessary and universal truth) to be the most primordial condition for human flourishing. Instead, the need for truth, truth at all cost, is a product of a certain set of circumstances and a long history.

Like Jung, Nietzsche avoids glib definitions of the 'human being'. Against Plato or Hobbes and Locke, Nietzsche denies that the human being is at all places and times a social being (Nietzsche 2007:23), but neither does he resemble Descartes' or Rousseau's solitary subjects. Sociality is more of a proclivity than an essence (Nietzsche 2002):

For as long as there have been people, there have been herds of people as well (racial groups, communities, tribes, folk, states, churches), and a very large number of people who obey compared to relatively few who command. (p. 86)

Like all other natural herds, human herds sought out the conditions under which they could flourish, and at his most Darwinian, Nietzsche does not deny that humanity has retained this animal nature. But as humans began to develop consciousness - and eventually also mental phenomena like the conscience - they began to seek something more, something meaningful, which took away the sense of the arbitrary that accompanies animal existence. Clans, herds and tribes began to develop into peoples (Volker), because humans came to understand that in order to have meaning, their physical being must be devoted to a way of life - a goal or a set of circumstances - which demands far beyond what is strictly necessary for survival or even comfort. This should be something that allows a human person or group to esteem.

Each 'people' or group develops its own way of life which is 'arduous' or 'difficult' in its own right: not only customs that need to be adhered to at pain of death or exclusion, but also increasingly gruelling tests, which only the elite (the masters) can pass. Each individual is called upon to 'test' themselves against the challenges set by such tests, developing both their own capacities and shaping the history of a people.

A people's culture is the history of the imaginative creation of such standards. Eventually, such standards are codified the Homeric imagination, the codes of Solon or Hammurabi, the Torah of the Jews, the Brahmins - in which a people's vision of themselves are aesthetically articulated (Nietzsche 1968:409). A horizon emerges, a comprehensive if essentially limited construction of the past - indeed the whole universewhich distorts, obscures and encaptures all experienced phenomena in order to protect the significance of every individual life. Every individual needs to be anchored and believe that their common life is inestimably valuable, as well as more permanent than their individual lives. According to Nietzsche, every individual needs to believe that he or she is anchored in something larger than themselves, which will continue after their individual deaths. Zarathustra calls this anchoring the 'spirit of gravity' - which echoes Jung's notion of symbols attracting the libido of the personal and collective unconscious - and it is a counterforce against nihilism. This protective horizon allows the individual to face the endless flux of becoming and to remain standing in a world where he is subject to forces beyond his control. Whilst Nietzsche is reluctant to use religious language in connection with the 'spirit of gravity', there is a clear connection between this notion and the formation of gods. The divine in Nietzsche is a complex notion that goes far beyond the scope of this article, but it will suffice to say that gods - especially as understood by the Greeks and other pagans - are symbolic manifestations of the need to overcome or to 'face' existence. In other words, gods are sublimations.

Christianity has always experienced tension between this particular demand and what Nietzsche calls 'the will to truth'. On the one hand, every culture, including Christian ones, needs its particular horizon to survive and the highly diverse history of Christian aesthetic achievement is evidence of that. On the other hand, the Christian demand for honesty compels the believer to examine everything, including himself or herself, his or her beliefs and eventually everything beyond the life-enhancing limits of his or her culture. Nothing can withstand this inhumane and unprecedented demand for honesty, including the Christian faith (Nietzsche 1994):

Christian morality itself, the concept of truthfulness which was taken more and more seriously, the confessional punctiliousness of Christian conscience, translated and sublimated into scientific conscience, into intellectual rigour at any price. Regarding nature as though it were a proof of God's goodness and providence; interpreting history in honour of divine reason, as a constant testimonial to an ethical world order and ethical ultimate purpose; explaining all one's own experiences in the way pious folk have done for long enough, as though everything were providence, a sign, intended, and sent for the salvation of the soul: now all that is over, it has conscience against it, every sensitive conscience sees it as indecent, dishonest, as a pack of lies, feminism, weakness, cowardice, - this severity makes us good Europeans if anything does, and heirs to Europe's most protracted and bravest 'self-overcoming!' ... All great things bring about their own demise through an act of self-sublimation: that is the law of life, the law of necessary 'self-overcoming' in the essence of life, - the lawgiver himself is always ultimately exposed to the cry: 'patere legem, quam ipse tulisti'. (p. 119) 
For Nietzsche, as for the Greeks, honesty is not to be regarded as a virtue at all costs. This 'naive' virtue has cost Christianity dearly (Nietzsche 1994):

In this way, Christianity as a dogma was destroyed by its own morality, in the same way Christianity as a morality must also be destroyed, - we stand on the threshold of this occurrence. After Christian truthfulness has drawn one conclusion after another, it will finally draw the strongest conclusion, that against itself; this will, however, happen when it asks itself, 'What does all will to truth mean?' ... and here I touch on my problem again, on our problem, my unknown friends (- because I don't know of any friend as yet): what meaning does our being have, if it were not that that will to truth has become conscious of itself as a problem in us? (p. 119)

Nietzsche's term for this state of affairs is the death of God. It should be clear that by this Nietzsche does not have a cataclysmic cosmological event in mind. The immediate interpretation that comes to mind is the difficulty of reconciling the literal truths of Christianity with the obvious empirical successes of the natural sciences and the concomitant spirit of skepticism that can be found in the materialist philosophers such as Feuerbach and Marx. But these thinkers are still comfortably ensconced within the general progressive myth of Christianity in their own version of meliorism - that the world is gradually getting better for everybody, as long as humanity grabs the opportunity to redeem itself.

More importantly, with the death of God Nietzsche refers to the decline of any meaningful significance of monotheism for European culture. European culture had gradually been losing its grip on God since the 18th century, but the effects have not been visible until now. For Nietzsche, the death of God is equivalent to the end of truth. Divine transcendence has long been the guarantor, horizon or frame for the variety of cultural phenomena, which emerged within its folds. Even philosophers or artists have vehemently claimed to reject God still depended upon the metaphysical categories implied by monotheism. Without the divine, humanity is left only with becoming, and secular systems which continue to seek a final redemption of the negativity of existence through an increasingly banal series of divine substitutes (i.e. moral idealism, facile humanistic optimism, scientism). No substitute succeeds, because all remain products of asceticism and desired withdrawal from the world (Nietzsche 1974):

In the horizon of the infinite - We have left the land and have embarked. We have burned our bridges behind us - indeed, we have gone farther and destroyed the land behind us. Now, little ship, look out! Beside you is the ocean: to be sure, it does not always roar, and at times it lies spread out like silk and gold and reveries of graciousness. But hours will come when you will realize that it is infinite and that there is nothing more awesome than infinity. Oh, the poor bird that felt free and now strikes the walls of this cage! Woe, when you feel homesick for the land as if it had offered more freedom - and there is no longer any 'land'. (p. 180)
The inevitable fate of monotheism turned Nietzsche not to atheism but to Greek polytheism for an alternative myth. The Greek gods are generally understood as symbols or personifications of human ideals. Like many other mythological panthea, the gods originally emerged as explanations for that which was geared. However, what set the Greeks apart was their power of sublimation: the gods became projected ideals. The most important instance of this is arguably the Apollo-Dionysus dichotomy, with Apollo representing the plastic arts, rational beauty and principles such as proportionality and balance and with Dionysus associated with passion, excess, intoxication and the sublime. Importantly for Nietzsche, the Greeks did not link their mythical experience to moral principles behind the world but formulated their cultural horizon within worldly aesthetic terms. Instead of a fully transparent world based upon unassailable foundations, Nietzsche offers a quasi-tragic or Heraclitian world, beyond control of the subject, but rich with infinite possibility. Because conceptual frameworks tend to rest upon arbitrary grounds, it allows for the choice of one with the greatest possible potential, so that the futility of being subject to the contingencies of existence is suppressed for as long as possible. What makes one mythological framework or horizon 'better' than another is not its verifiability but its ability to stimulate life thoroughly and to discharge the maximum amount of potentia. The chief complaint that Nietzsche has against Platonic and Christian metaphysics is that it works counter to this purpose. In Nietzsche's universe, life becomes a terrifying and tragic play of power within the unavoidable torrent of becoming. This world also recovers a lost innocence and a renewed notion of freedom. Whilst frightening, it offers the possibility of true tragic greatness for Nietzsche the only form of life truly worth living. Now humanity becomes free to create itself afresh; it is limited to neither an absolute end nor a moral telos. Nietzsche makes a case for the complete liberation from moral ends; only acceptance of the innocence of becoming can give us genuine freedom.

Unlike the rigid transcendent differentiation of Platonic metaphysics, pre-Platonic differentiation and distinction occurred within, according to the operation of the agon. In the simplest sense, agon means contest or competition. It is, however, not a contest of annihilation (Vernichtungskampf) in which 'the winner takes all', but a key aspect of pre-Socratic Greek culture; and a limited and fecund form of contestation (Wettkampf), in which adversaries (as opposed to enemies compete with one another in a process of reciprocated enablement and provocation and which is limited in the process by mutual disempowerment or restraint. Rather than separating nature from culture, Nietzsche offers an enriched and ennobled concept of human nature, inspired by an allencompassing natural capriciousness. Note his refusal to censor the potential of the 'negative parts' of Nature (later echoed by Jung). Instead, he gives us an institution linked with the instinct for play and the ebb and flow of life (Nietzsche 1994): 
If we speak of humanity, it is on the basic assumption that it should be that which separates man [sic] from nature and is his mark of distinction. But in reality there is no such separation: 'natural' characteristics and those called specifically 'human' have grown together inextricably. Man [sic], at the finest height of his powers, is all nature and carries nature's uncanny dual character in himself. His dreadful capabilities and those counting as inhuman are perhaps, indeed, the fertile soil from which alone all humanity, in feelings, deeds and works, can grow forth. (p. 174)

The key to understanding the Greeks is the notion of productive and inclusive conflict. The Greeks even had a goddess of conflict, who was truly beyond good and evil. Eris may be said to be the inspiring divinity of the agon. The point of Homer's Contest is to demonstrate how the Greeks turned the potentially evil Eris of annihilation into the 'good' Eris of productive conflict. In contrast to the 'measureless' Christian tradition that tries to expunge all forms of negativity and so safeguards itself, the Greeks prevented the destruction of culture by sublimating the forces of destruction. In this way, even the negative forces were pressed into forming and maintaining that life-giving horizon of cultural enclosure. The dramatic potentia of base, damaging forces were acknowledged and used as stimulus (Reiz) in a process of measured discharge in contests that ruled virtually all aspects of Greek life. Ability must unfold itself in conflict; otherwise, the twin evils of autocracy and barrenness will follow. As a great stimulant, the agon curtails this: a great author who resents his predecessor is challenged by the latter's achievements into producing masterpieces of his own, and even to outshine his rival, living or dead (Nietzsche 1994):

And not just Aristotle, but the whole of Greek antiquity thinks about grudge and envy differently from us and agrees with Hesiod, who first portrays one Eris as wicked, in fact the one who leads men into hostile struggle-to-the-death, and then praises the other Eris as good who, as jealousy, grudge and envy, goads men to action, not, however, the action of a struggle-tothe-death but the action of the contest. (p. 177)

And action is life.

\section{Jung, myth and the process of integration}

Whilst perhaps the most unequivocal diagnostician of the ills of modernity, Nietzsche was hardly the only thinker to address the problem of the meaninglessness of modernity. Thinkers ranging from Marx to Simmel and Baudelaire have done so, but unlike them, Nietzsche is no meliorist. He does not accept any theses of human 'improvement' - let alone one based upon social conditions. He refuses to find any hope for humanity in just improving the material conditions of its existence: he wants to know why this endeavour would be worth the effort. However, as Giles Fraser argues in Nietzsche: The Piety of Unbelief (Fraser 2002:122-139), Nietzsche (as well as his 19th-century intellectual compatriots) had the luxury of writing before the two world wars and the rise of totalitarianism. Since then the world had to face the consequences of the meltdown of the Cold War, an ever- growing abyss between rich and poor and the displacement of millions of refugees. Even if the present article remains within the realm of theory, it can be valuable to turn to a thinker who addressed a wider range of lived human experience. Given our dialogue with the Global Risks 2035 report (2019), we turn towards a later German thinker, Carl Gustav Jung, for a more affirmative answer to the nihilism, which appears to have become a part of 21st century life.

Despite Carl Jung's extremely broad range of interests on matters spanning religion, culture, anthropology and mysticism, it remains a fact that he approached these matters consistently through the lens of the psyche, speaking as the psychologist that he was about matters of psychological life and meaning rather than about any external reality as such (such as the question whether God exists objectively 'out there'). Indeed, 'Jung's work was amongst the first serious attempts to meaningfully engage psychology with meaning' (Jones 2007:204). He interprets myths as windows into the unconscious or preconscious activities of the psyche (Jung 1968:154) so that the subject matter symbolises not the objective but the subjective world (Segal 1999:67). This both included and transcended the individual psyche through Jung's postulation of the collective unconscious, which he described as the 'supra-individual universality' of the unconscious (Jung 1990:177; Jones 2007:206). In essence, this is an innate understanding of (or orientation to) the world that is shared by all people and which explains recurring themes in myths (Minier 1997:44). Themes in the unconscious compound around images that Jung called archetypes and although he understood them to originate in a reality outside time and space, they manifest through the individual psyche where they serve as organisers (Storr 1998:25), giving rise to recurring patterns in myths, dreams and stories (Minier 1997:44).

Jung described psychopathology from the perspective of fragmentation between sub-aspects of the person. Without diverting into this complex subject, it is important to note that the Self - as archetype that gravitates the psyche towards wholeness - describes a unifying principle within the psyche. It is not an exaggeration to state that Jung's 'entire psychological theory is founded on the presupposition of the human potential for wholeness and is an elaboration and detailed explication of that primary datum' (Stein 1994:33). Once this is understood, it becomes easier to grasp the importance that Jung gave to myth, and specifically to religious (and the Christian) myth. Jung described the process of individuation, or the psyche's natural transformative integration towards wholeness between all the various elements of the psyche, both conscious and unconscious, as a religious quest of sorts (Storr 1998:238). Whilst Jung was profoundly influenced by Nietzsche, he differed from him in that he 'rediscovered God as a guiding principle of unity within the depths of the individual psyche' (Storr 1998:25). Despite the decidedly negative personal experiences of religion in his younger years, the religious content of the multiple expressions of the psyche that confronted him 
through his patients and research, returned him to the insistent question of religion (Dourley 1994:125). This eventually culminated in his description of an 'authentic religious function' that served the purpose of guiding the human person towards wholeness (Dourley 1994):

In this manner Jung came to equate without residue psychological maturity and authentic religious experience. Their identity rests on the natural teleology of the psyche towards wholeness, a teleology which works to unify the many powers that constitute the individual even as it breeds in the individual an empathic identity with the totality. (p. 125)

The difference was that Jung shifted this force for unity from outside to inside the psyche. Christ, in short, functioned as a symbol for the archetype of the Self, which is the organising principle towards wholeness. The Christian myth, with its symbol of the dying and rising God signalling the tendency of the psyche towards transformation and integration, had captivated the libido ${ }^{3}$ of large parts of the world for centuries. However, the rationale for the decline of this myth may be found in its aversion to wholeness, because what excludes evil and the feminine principle can 'no longer symbolise wholeness for modern man [sic]' (Storr 1998:26). Here we find an echo of Nietzsche's notion of Christianity bearing its seed of destruction within itself, this time because of its opposition to certain aspects of life. Because the potential for unity lies in the archetype of the Self - an organising principle for wholeness in the psyche the psychic energy is withdrawn from the outdated symbol (Christ) that no longer effectively catapults the attention of the psyche towards integration.

The problem is that a new symbol or myth that might draw the libido of contemporary humanity towards integration has not emerged in the place of the Christian myth. The risk according to Jung was that humanity, with its naturally religious attitude [read: inclination towards wholeness], when unable to subscribe to a religious myth would substitute it with the inferior worship of the state (Storr 1998:238). The height of nihilism in our day is that, whilst the idea of 'God' represented the supreme value to the generations of yesteryear (Von Franz 1998:16), humanity today has no unifying symbol that holds its collective consciousness and expresses its supreme value. This is Nietzsche's death of God in the Jungian sense, and this is the void of meaning that underlies the failures of global leadership in the wake of our most challenging collective problems. It engenders the rise of populist politics and the resulting polarisation between nation-states, as well as the compulsion to stockpile material possessions, exotic experiences and social media comments to compensate for the haunting emptiness that only wholeness can fill. As the quote at the beginning of our article suggests, the God [unifying tendency of the psyche] will be present, whether acknowledged or not. In the absence of a unifying myth that facilitates the journey towards integration of the individual psyche, this inclination will be projected to ideations of the state that undermine the individual's crucial calling towards individuation.

In Jung's system of thought, the unconscious is on a path of self-expression and integration. This is Jung's personal myth that he adapted from the Gnostic pleroma, and which reflects Schopenhauer's idea that individuals expressed in the physical a Will that gave rise to everything but which itself lay beyond space and time (Storr 1998:24). Although Jung admitted that he had been influenced by Schopenhauer, he digressed from him by affirming individuality (like Nietzsche), which Schopenhauer attempted to escape by means of self-denial and asceticism (Storr 1998:24). This is the context of his defining quote in the beginning of Memories, Dreams, Reflections (Jung 1989):

My life is a story of the self-realization of the unconscious. Everything in the unconscious seeks outward manifestation, and the personality too desires to evolve out of its unconscious conditions and to experience itself as a whole. I cannot employ the language of science to trace this process of growth in myself, for I cannot experience myself as a scientific problem. What we are to our inward vision, and what man [sic] appears to be sub specie aeternitatis, can only be expressed by way of myth. Myth is more individual and expresses life more precisely than does science. Science works with concepts of averages which are far too general to do justice to the subjective variety of an individual life. Thus it is that I have now undertaken, in my eighty-third year, to tell my personal myth. I can only make direct statements, only 'tell stories'. Whether or not the stories are 'true' is not the problem. The only question is whether what I tell is my fable, my truth. (p. 3)

As the English translator of the German C.G. Jung: Sein Mythos im unserer Zeit (Von Franz 1972 [English 1975, 1998]) put it in his translator's note, 'Jung lived a universal story, or myth; but he lived it individually, concretely, fully ...' Such is the balance that is needed in a unified myth that can at once unify humanity's collective unconscious towards a shared goal, yet only in and through the concrete and the particular expression of this or that human person within the context of this or that cultural inheritance and this or that language. The metaphor of the Trinity in Christianity is such an example, as it was crafted through the invention of new language to safeguard both unity and particularity. Similarly, humanity requires a new shared myth or new meta-narrative. This is the idea of transcendence in and through immanence - the particular 'thisness' (haecceitas) (Kearney, Veldsman \& Steenkamp 2018:314) that must be maintained, sustained.

\section{Conclusion}

As we return to the challenges of our contemporary world, it is hard to overstate the challenge to global leadership in a world that seems flung from one crisis to the next, with leaders responding to one after the other in seeming isolation and with lack of a coherent strategic vision. Having sketched its three scenarios for the global future and ending with the possibility of an increasing decline into chaos, the Global Risks 2035 Update report asks (Burrows 2019): 
Is there any way to stop the descent? No leader believes he or she has the means to stop it. At home in all the major powers, growing populism, nativism, and jingoism come to the fore, militating against saving the world. (p. 12)

It has become clear from our study that the demand placed on leadership cannot merely be 'better integration of strategic foresight into decision making' as the Update report suggests (Burrows 2019:12). Instead, the author anticipates a more transformative and sustainable approach in his short conclusion, with its reference to shared meaning. What further stems from this is that the social constructionist perspectives on meaning in leadership is an important start, although nowhere near sufficient to deal with the nihilism that threatens to destroy our societies from within. The scale and frequency of disruptions that global leadership faces in our world - what Gowing and Langdon (2018) call 'unthinkable' impacts, from the 2007 and 2008 financial collapse to the Fukushima nuclear disaster, Brexit, the election of Donald Trump and, yes, COVID-19, to name a few - and the less than adequate response by leadership underscore the absence of what Jung would call a unifying myth. For Nietzsche, this lack of meaning exposes the Last Man, or a society devoid of value and achievement that pacifies itself on luxury and safe averages. That humanity might very well fail to survive this insistence on safe averages only emphasises the imperative that leadership for the current epoch should return to the urgent question of meaning. This cannot be yet another version of 'us' against 'them' that condemns the world to increased state-on-state conflict. Neither can it be a romanticised anthem of unity, that undermines the freedom and particularity of the individual and undercuts the particularity of the diverse cultures of the world. This returns leadership studies to a deep philosophical, and yes, spiritual reflection that again - with all due respect to the insight that leadership is a social construction - takes the personal stories of individual leaders and followers seriously. Perhaps Jung's starting words as he contemplated the spiritual problem of contemporary humanity in Modern man in search of a soul is a good place for leadership studies to start (Jung 1933):

The spiritual problem of modern man [sic] is one of those questions which belong so intimately to the present in which we are living that we cannot judge of them fully. The modern man is a newly formed human being, a modern problem is a question which has just arisen and whose answer lies in the future. (p. 226)

\section{Acknowledgements Competing interests}

The authors declare that they have no financial or personal relationships, which may have inappropriately influenced them in writing this article.

\section{Authors' contribution}

M.L.M. and Y.S. contributed equally to this work.

\section{Ethical considerations}

This article followed all ethical standards for a research without direct contact with human or animal subjects. The authors confirm that ethical clearance was not needed or required for the study.

\section{Funding information}

This research received no specific grant from any funding agency in the public, commercial or not-for-profit sectors.

\section{Data availability}

Data sharing is not applicable to this article as no new data were created or analysed in this study.

\section{Disclaimer}

The views or opinions expressed in this article are those of the authors and do not necessarily reflect the official policy or position of any affiliated agency of the authors.

\section{References}

Berlin, I. (ed.), 1956, The age of enlightenment: The eighteenth century philosophers, Mentor Philosopher Series, The New American Library, New York, NY.

Bradbury, H. \& Lichtenstein, B., 2000, 'Relationality in organizational research: Exploring the "space between"', Organization Science 11(5), 551-564. https://doi. org/10.1287/orsc.11.5.551.15203

Burrows, M.J., 2019, 'Decline or new renaissance? Global risks 2035 update', Atlantic Council Strategy Papers, Atlantic Council, Washington, DC, viewed 27 May 2020, from https://www.atlanticcouncil.org/in-depth-research-reports/report/globalrisks-2035-update/.

Carson, J.B., Tesluk, P.E. \& Marrone, J.A., 2007, 'Shared leadership in teams: An investigation of antecedent conditions and performance', Academy of Management Journal 50(5), 1217-1234. https://doi.org/10.2307/20159921

Conway, J.A., 2015, 'Relational leadership as meaningful co-action', PhD thesis, University of Glasgow, viewed 27 May 2020, from http://theses.gla.ac.uk/6777/.

Dachler, H.P. \& Hosking, D.M., 1995, 'The primacy of relations in socially constructing organizational realities', in D.M. Hosking, H.P. Dachler \& K.J. Gergen (eds.), Management and organization: Relational alternatives to individualism, pp. 1-29, Aldershot, Avebury.

Day, D.V. \& Antonakis, J. (eds.), 2012, The nature of leadership, 2nd edn., Sage, Thousand Oaks, CA.

Dourley, J.P., 1994, 'In the shadow of the monotheisms: Jung's conversation with Buber and White', in J. Ryce-Menuhin (ed.), Jung and the monotheisms: Judaism, Christianity and Islam, pp. 125-145, Routledge, London.

Fraser, G., 2002, Nietzsche: The piety of unbelief, Routledge, New York, NY.

Fremantle, A.J. (ed.), 1955, The age of belief: The medieval philosophers, The New American Library, New York, NY.

Gowing, N. \& Langdon, C., 2018, Thinking the unthinkable: A new imperative for leadership in a disruptive age, John Catt Educational, Melton.

Hampshire, S. (ed.), 1956, The age of reason: The seventeenth century philosophers, Great Ages of Western Philosophy, vol. 3, Houghton Mifflin, Boston, MA.

Jones, R.A., 2007, 'A discovery of meaning: The case of C. G. Jung's house dream', Culture \& Psychology 13(2), 203-230. https://doi.org/10.1177/1354067X070 76596

Jung, C.G., 1933, Modern man in search of a soul, transl. W.S. Dell \& C.F. Baynes, Kegan Paul, Trench, Trubner \& Co, London.

Jung, C.G., 1968, 'The Archetypes and the collective unconscious', in H. Read, M Fordham \& G. Adler (eds.), Collected works, vol. 9, part 1, transl. R.F.C. Hull, 2 nd edn., Routledge, London.

Jung, C.G., 1989, Memories, dreams, reflections, Recorded and edited by A. Jaffé, transl. Richard and C. Winston, Rev. edn., Vintage Books, New York, NY.

Jung, C.G., 1990, 'Symbols of transformation: An analysis of the prelude to a case of schizophrenia', in H. Read, M. Fordham \& G. Adler (eds.), Collected works, vol. 5. Executive ed. W. McGuire, transl. R.F.C. Hull, 2 nd edn., Bollingen Series 10, Princeton University Press, Princeton, NJ. 
Kearney, R., Veldsman, D.P. \& Steenkamp, Y., 2018, 'Across oceans: A conversation on otherness, hospitality and welcoming a strange God', in D.P. Veldsman \& Y. Steenkamp (eds.), Debating otherness with Richard Kearney: Perspectives from Steenkamp (eds.), Debating otherness with Richard Kearney: Perspectives from
South Africa, pp. 307-342, AOSIS, Cape Town. https://doi.org/10.4102/ South Africa, pp.
aosis.2018.BK94.15

Kempe, F., 2020, 'U.S.-China confrontation is like nothing we've seen before', Atlantic Council: Inflection Points, 26 July 2020, viewed 27 May 2020, from https://www. atlanticcouncil.org/content-series/inflection-points/us-china-confrontation-coldwar-ii-is-like-nothing-we-have-seen-before/.

Lyotard, J.-F., 1984, The postmodern condition: A report on knowledge, edited and translated by G. Bennington \& B. Massumi, with a foreword by F. Jameson, Manchester University Press, Manchester.

Maak, T. \& Pless, N.M., 2006, 'Responsible leadership in a stakeholder society: A relational perspective', Journal of Business Ethics 66(1), 99-115. https://doi. org/10.1007/s10551-006-9047-z

Maak, T. \& Pless, N.M., 2019, 'Responsible leadership: Reconciling people, purpose, and profit', in S. Kempster, T. Maak \& K. Parry (eds.), Good dividends: Responsible leadership of business purpose, pp. 30-36, Routledge, NY

Minier, S., 1997, 'An "authentic wholeness" synthesis of Jungian and existential analysis', Modern Psychological Studies 5(2), Article 3, 43-51, viewed 27 May 2020, from https://scholar.utc.edu/mps/vol5/iss $2 / 3$.

Nietzsche, F., 1968, The will to power, transl. W. Kaufman, Vintage, New York, NY

Nietzsche, F., 1974, The gay science: With a prelude in rhymes and an appendage of poems, edited and transl. by W. Kaufman, Vintage, New York, NY.
Nietzsche, F., 2002, Beyond good and evil: Prelude to a philosophy of the future, Rolf-Peter Horstman (ed.) and transl. J. Norman, Cambridge University Press, Cambridge.

Nietzsche, F., 2006, Thus Spoke Zarathustra: A book for all and none, edited and transl. A. Del Caro, Cambridge University Press, Cambridge.

Nietzsche, F., 2007, The genealogy of morals, K. Ansell-Pearson (ed.) and transl. C. Diethe, Cambridge University Press, Cambridge.

Segal, R.A., 1999, Theorizing about myth, University of Massachusetts Press, Amherst.

Stein, M., 1994, 'The dream of wholeness', in J. Ryce-Menuhin (ed.), Jung and the monotheisms: Judaism, Christianity and Islam, pp. 33-40, Routledge, London.

Storr, A., 1998, The essential Jung: Selected writings, Selected and Introduced by A. Storr, Fontana Press, London.

Uhl-Bien, M., 2006, 'Relational leadership theory: Exploring the social processes of leadership and organizing', The Leadership Quarterly 17(6), 654-676. https://doi. org/10.1016/j.leaqua.2006.10.007

Von Franz, M.-L., 1998, C.G. Jung: His myth in our time, transl. W.H. Kennedy, Inner City Books, Toronto, Originally published in 1975 by the C.G. Jung Foundation for Analytical Psychology, New York, First published in 1972 in German by Verlag Huber \& $\mathrm{Co}$.

White, M. (ed.), 1956, The age of analysis: The 20th century philosophers, Mentor Philosopher Series, The New American Library, New York, NY.

Zizek, S., 2002, Welcome to the desert of the real: Five essays on September 11 and related dates, Verso London. 